Article (refereed)

Cape, J N.; van der Eerden, L. J.; Sheppard, L. J.; Leith, I. D.; Sutton, M. A.. 2009 Evidence for changing the Critical Level for ammonia. Environmental Pollution, 157 (3). 1033-1037. doi:10.1016/j.envpol.2008.09.049

Copyright (c) 2009 Elsevier B.V.

This version available at http://nora.nerc.ac.uk/4442/

NERC has developed NORA to enable users to access research outputs wholly or partially funded by NERC. Copyright and other rights for material on this site are retained by the authors and/or other rights owners. Users should read the terms and conditions of use of this material at http://nora.nerc.ac.uk/policies.html\#access

This document is the author's final manuscript version of the journal article, incorporating any revisions agreed during the peer review process. Some differences between this and the publisher's version remain. You are advised to consult the publisher's version if you wish to cite from this article.

http://www.elsevier.com/ 


\title{
Evidence for changing the Critical Level for ammonia
}

\author{
J N Cape ${ }^{1}$, L J van der Eerden ${ }^{2}$, L J Sheppard ${ }^{1}$, I D Leith ${ }^{1}$ and M A Sutton ${ }^{1}$ \\ ${ }^{1}$ Centre for Ecology \& Hydrology, Edinburgh Research Station, Bush Estate, \\ Penicuik, EH26 0QB, UK \\ ${ }^{2}$ Foundation OBRAS, Centre for Art and Science, Evoramonte, Portugal. \\ The long-term critical level for $\mathrm{NH}_{3}$ has been revised down to $1 \mu \mathrm{g} \mathrm{m} \mathrm{m}^{-3}$ for the most sensitive plant species.
}

\begin{abstract}
The current Critical Level for ammonia $\left(\mathrm{CLE}_{\mathrm{NH} 3}\right)$ in Europe is set at $8 \mu \mathrm{g} \mathrm{NH}_{3} \mathrm{~m}^{-3}$ as an annual average concentration. Recent evidence has shown specific effects of ammonia $\left(\mathrm{NH}_{3}\right)$ on plant community composition (a true ecological effect) at much smaller concentrations. The methods used in setting a $\mathrm{CLE}_{\mathrm{NH} 3}$ are reviewed, and the available evidence collated, in proposing a new $\mathrm{CLE}_{\mathrm{NH} 3}$ for different types of vegetation. For lichens and bryophytes, we propose a new $\mathrm{CLE}_{\mathrm{NH} 3}$ of $1 \mu \mathrm{g} \mathrm{NH}_{3} \mathrm{~m}^{-3}$ as a long-term (several year) average concentration; for higher plants, there is less evidence, but we propose a $\mathrm{CLE}_{\mathrm{NH} 3}$ of $3 \pm 1 \mu \mathrm{g} \mathrm{NH}_{3} \mathrm{~m}^{-3}$ for herbaceous species. There is insufficient evidence to provide a separate $\mathrm{CLE}_{\mathrm{NH} 3}$ for forest trees, but the value of $3 \pm 1 \mu \mathrm{g} \mathrm{NH} \mathrm{N}_{3} \mathrm{~m}^{-3}$ is likely to exceed the empirical Critical Load for $\mathrm{N}$ deposition for most forest ecosystems.
\end{abstract}

\section{Introduction}

The Critical Level (CLE) for air concentration of a pollutant gas is defined as "the concentration in the atmosphere above which direct adverse effects on receptors, such as plants, ecosystems or materials, may occur according to present knowledge" (Posthumus, 1988). This definition means that when direct adverse effects of a gas are shown to occur at concentrations below the accepted Critical Level, 'present knowledge' must be updated and the Critical Level reviewed. In contrast, the Critical Load (CLO) is defined as "a quantitative estimate of deposition of one or more pollutants below which significant harmful effects on specified elements of the environment do not occur according to present knowledge" (Posthumus, 1988).

The distinction between the definitions is important; it is much more difficult to demonstrate the absence of an effect (to test the CLO) than the presence of an effect (to challenge the CLE). There is a more fundamental difference which is not included in the specific definitions given above, the inclusion of time frames. In general, CLEs are expressed in terms of threshold concentrations not to be exceeded over 1 hour, 1 day, 1 month or 1 year, while the CLO is defined in terms of long-term potential effects (several decades) (van der Eerden et al., 1991). This is because CLOs are usually seen as operating through soil and water rather than directly on vegetation, whereas CLEs refer to direct effects of airborne gases on the vegetation. The differences in applying CLEs and CLOs to nitrogen-containing pollutants (including ammonia) are summarised in Table 1. 
Table 1. Current differences in practice between Critical Levels (CLEs) and Critical Loads (CLOs) for N-containing air pollutants.

CLE

CLO

\begin{tabular}{|c|c|c|}
\hline Summarized definition & $\begin{array}{l}\text { Concentration above which effects } \\
\text { may occur }\end{array}$ & $\begin{array}{l}\text { Deposition below which effects do } \\
\text { not occur }\end{array}$ \\
\hline Exposure duration: & Short term (1 yr or less) & Long term $(+10$ yrs $)$ \\
\hline $\begin{array}{l}\text { Effect of peak } \\
\text { exposures }\end{array}$ & Included & Neglected \\
\hline Agent: & Separate CLE for each N-compound & All N-compounds added \\
\hline Object of interest: & Individual plant species & $\begin{array}{l}\text { Natural vegetation or forests; soils } \\
\text { and freshwaters (ecosystems) }\end{array}$ \\
\hline No effect concentration: & $\begin{array}{l}\text { Generally: the lowest statistically } \\
\text { significant response observed in } \\
\text { experiments }\end{array}$ & $\begin{array}{l}\text { Generally: estimate of a "safe" } \\
\text { deposition level derived from } \\
\text { empirical evidence or modelling. }\end{array}$ \\
\hline Goal: & Protection of sensitive plant species & $\begin{array}{l}\text { Protecting proper functioning of } \\
\text { ecosystems }\end{array}$ \\
\hline Combination effects & Possibility of synergism is considered & $\begin{array}{l}\text { Additivity is presumed (i.e. all forms } \\
\text { of } N \text { have same effects) }\end{array}$ \\
\hline
\end{tabular}

CLEs for $\mathrm{NH}_{3}\left(\mathrm{CLE}_{\mathrm{NH} 3}\right)$ were first defined at the UNECE Bad Harzburg workshop (Posthumus, 1988) and then revised at the UNECE Workshop in Egham, UK, in 1993 (Ashmore and Wilson, 1994). There have been several subsequent reviews on the effects of $\mathrm{NH}_{3}$ on vegetation (Fangmeier et al., 1994, Krupa, 2003, van der Eerden et al., 1994, WHO, 1997). The issues involved in addressing the CLE $\mathrm{NH}_{33}$ and highlighted in the review articles have been summarised (Cape et al., 2008) in the proceedings of a workshop held in Edinburgh in December 2006 under the auspices of the United Nations Economic Commission for Europe (UNECE) (Sutton et al., 2008a). This paper presents the rationale for reassessing the concept of a $\mathrm{CLE}_{\mathrm{NH} 3}$, including the procedures used to establish the threshold concentration at which effects are observed, then examines the recent evidence for effects of $\mathrm{NH}_{3}$ on vegetation at concentrations below the original annual $\mathrm{CLE}_{\mathrm{NH} 3}$ of $8 \mu \mathrm{g} \mathrm{m} \mathrm{m}^{-3}$, leading to conclusions and recommendations for new $\mathrm{CLE}_{\mathrm{NH} 3}$ for sensitive vegetation types.

\section{Evidence for reassessing the $\mathbf{C L E}_{\mathrm{NH} 3}$}

Much of the debate over the effects of $\mathrm{NH}_{3}$ on vegetation arises over the distinction between direct effects of the gas on the above-ground vegetation, and the role of $\mathrm{NH}_{3}$ in acting as a source of dry-deposited nitrogen $(\mathrm{N})$ to the soil or substrate, adding to the CLO for N. In practice, the current annual $\mathrm{CLE}_{\mathrm{NH} 3}$ of $8 \mu \mathrm{g} \mathrm{m}^{-3}$ does not protect vegetation in Europe because the CLO for $\mathrm{N}$ deposition would be exceeded in most ecosystems from the dry deposition of $\mathrm{NH}_{3}$ long before any direct effects would be expected to occur on the basis of the current annual CLE $\mathrm{NH}_{\mathrm{NH}}$ (Cape et al., 2008). In terms of setting CLEs, the critical question to be answered is whether (in terms of the definition above) a 'direct adverse effect on the receptor' of $\mathrm{NH}_{3}$ can be demonstrated as distinct from any contribution of $\mathrm{NH}_{3}$ to $\mathrm{N}$ deposition and soil-mediated effects. Although changes in vegetation properties (e.g. tissue $\mathrm{N}$ concentrations) can be observed in response to $\mathrm{NH}_{3}$ (Sheppard et al., 2008b) there is generally no indication of the long-term consequences of such changes, whether adverse or otherwise. The evidence presented below is therefore derived from field-based observations of changes in populations of vegetation, where the evidence for an adverse effect is demonstrated in terms of the loss of one or more species from a community, or radical changes in the proportions of species in a community. This is a very different 
approach from that used in the initial setting of the $\mathrm{CLE}_{\mathrm{NH} 3}$, which made extensive use of laboratory experiments on plants, often species with a high $\mathrm{N}$ demand, growing as single species or cultivars in monocultures at constant $\mathrm{NH}_{3}$ concentrations (Posthumus, 1988).

In deriving a CLE $\mathrm{NH}_{\mathrm{NH}}$ from field observations, the causal relation of the exposure with an ecologically relevant end-point should be clear and quantified. Field observations also can include the interactions (in terms of effects) between $\mathrm{NH}_{3}$ exposure and environmental conditions. There is evidence of enhanced sensitivity of plants to $\mathrm{NH}_{3}$ during drought and cold, and vegetation may become more sensitive to insect or pathogen attack, or to strong winds after exposure to $\mathrm{NH}_{3}$ (Sheppard et al., 2008b, van der Eerden et al., 1991, van der Eerden et al., 2008). However, the field observations used to derive the $\mathrm{CLE}_{\mathrm{NH} 3}$ will not have encompassed the full range of possible environmental conditions. Consequently, exceedance of the $\mathrm{CLE}_{\mathrm{NH} 3}$ does not guarantee that an effect will be observed, nor does it guarantee that no effect will be observed in the presence of particular environmental stresses. Interactions with other gaseous pollutants are also poorly understood. There is experimental evidence of increased deposition rates of $\mathrm{SO}_{2}$ in response to $\mathrm{NH}_{3}$ (Cape et al., 1995), and of increased $\mathrm{NH}_{3}$ deposition in response to $\mathrm{SO}_{2}$ (Shaw and McLeod, 1995). However, interaction with $\mathrm{SO}_{2}$ might be expected to lead to increased deposition to external leaf surfaces, and localised depletion of gas-phase $\mathrm{NH}_{3}$ near stomata, thereby reducing internal uptake and $\mathrm{NH}_{3}$ effects.

Much, but not all, of the evidence presented here is derived from observations made downwind of large intensive animal production units, which are the major point sources of $\mathrm{NH}_{3}$ in the landscape. Consequently, we need to demonstrate that the causal agent in any effects is likely to be $\mathrm{NH}_{3}$ rather than another material emitted from such sources. Corroborative evidence will be given from a long-term field fumigation study of an ombrotrophic bog which used pure $\mathrm{NH}_{3}$ (Leith et al., 2004). In all cases, the evidence is supported by measurements of $\mathrm{NH}_{3}$ concentrations at the sites of interest.

Emissions from intensive livestock rearing units contain a cocktail of compounds including $\mathrm{NH}_{3}$, carbon dioxide, gaseous amines and particles containing nutrients, including nitrogen, phosphorous and potassium. It is possible that nutrient-containing particles (dust) could play a part in any observed effects on vegetation. However, the spatial pattern of dust deposition to the landscape is rather different from that for $\mathrm{NH}_{3}$; large particles $\left(>10^{-6} \mathrm{~m}\right.$ diameter) deposit rapidly, within a few tens of metres, whereas sub-micron particles are inefficiently scavenged by vegetation and may be dispersed over tens or even hundreds of km (Pryor et al., 2008). Ammonia, however, is likely to have effects up to a few hundred metres downwind, depending on the size of the source (Pitcairn et al., 2002). $\mathrm{CO}_{2}$ is emitted in large quantities in co-occurrence with $\mathrm{NH}_{3}$, but again its impact on the $\mathrm{NH}_{3}$ effect is probably negligible (Perez-Soba et al., 1994). Wet $\mathrm{N}$ deposition is unlikely to change markedly over short distances from the source; any increases in $\mathrm{N}$ deposition measured in throughfall close to point sources are most likely attributable to the removal of soluble dry deposition (mostly $\mathrm{NH}_{3}$ ) from plant surfaces (Cape et al., 1995) rather than direct incorporation into falling rain. The evidence presented below relies strongly on observations of lichen and bryophyte communities in response to measured $\mathrm{NH}_{3}$ concentrations. These 
communities are least likely to be influenced by $\mathrm{N}$ supply from the substrate, and therefore are good indicators of a direct effect of $\mathrm{NH}_{3}$ in the gas phase.

\section{Procedures for deriving a CLE from an exposure-response relationship}

In order to establish a CLE from field observations, the main difficulty is to establish an appropriate background exposure which is below the presumed 'no observed effect concentration' (NOEC). Air concentrations in remote rural areas of Europe are well below $1 \mu \mathrm{g} \mathrm{NH}_{3} \mathrm{~m}^{-3}$, and, given the relatively short transport distance of gaseous $\mathrm{NH}_{3}$ in the atmosphere (tens rather than hundreds of $\mathrm{km}$ ) may be assumed to be close to a true 'background'. However, for many regions of Europe the regional 'background' concentration may be several $\mu \mathrm{g} \mathrm{NH}_{3} \mathrm{~m}^{-3}$, and changes in plant communities may have already occurred many decades ago. For those regions 'background' conditions may have to relate to the $19^{\text {th }}$ century rather than to any currently available. There is documented evidence, for example, of the loss of cyanobacterial lichens in the Netherlands over the past century (WHO, 1997). This problem also arose with some of the early experimental approaches to determining NOECs, where the 'control' $\mathrm{NH}_{3}$ concentration was several $\mu \mathrm{g} \mathrm{NH} \mathrm{N}_{3}^{-3}$ (van der Eerden et al., 1991).

We therefore need to establish, for any given location where vegetation is exposed to a source of $\mathrm{NH}_{3}$, the point at which significant changes can be observed. The word 'significant' refers to both ecological and statistical significance. Responses in terms of growth, vitality, reproductive fitness, competitive ability, shifts in species composition etc. can be regarded as having ecological significance. But for some other responses to exposure to $\mathrm{NH}_{3}$, such as enhanced foliar contents of $\mathrm{N}$, arginine or $\mathrm{NH}_{4}^{+}$, Glutathione synthetase activity etc., the relationships with ecological end points and their dependence on environmental conditions are still insufficiently quantified even at the species level for them to be used directly as a basis for setting CLEs. In statistical terms, 'significant' means that the measurement exceeds the 'background' value, and has only a small probability (e.g. $<5 \%$ ) of falling within the range of possible values regarded as 'background' - this depends inter alia on the inherent uncertainty of the measurement method and the spatial (and temporal) variability of the measured vegetation. In some cases the exposure/response relationship shows a clear break point - the point above which the response deviates from the values observed at low concentrations - and continues to increase in response to increasing concentrations. However, for most of the new information presented here we do not know the true 'background' or 'no-effect' concentration, and so have had to rely on a statistical procedure to identify the point at which an effect is detectable that is statistically significantly different from that observed at the lowest concentrations observed at a given field site.

The method used to identify the apparent NOEC is illustrated in Figure 1. The equation of the line that best fits the response data in terms of the measured $\mathrm{NH}_{3}$ concentration was established by means of a least-squares analysis. The $95 \%$ confidence limits for the relationship can than be calculated. The upper $95 \%$ curve at the lowest exposure concentration estimates the largest value of the response variable that falls within the local 'background' range (the lowest concentration measured; point $A$ in Figure 1). If this response value is extended to higher concentrations, the point where it intersects the fitted curve (point B) indicates the lowest concentration that yields a measurement value above the local 'background' (read from the x-axis at point $\mathrm{C}$ ). This limiting concentration (C) is then an indication of the NOEC obtained 
from that data set. This procedure utilises all the information available (in fitting the relationship) while focussing on the lower end of the exposure scale. A measure of the appropriateness of the sampling regime (number of samples at any location) can be ascertained from the relationship between the spread of measurement data about the mean and the range of the fitted curve. In general, for the data available, either a linear or log-linear response curve has been used, although other forms of response (e.g. sigmoidal) could exist and be used in a similar fashion.

This approach is a pragmatic solution to situations where the true NOEC may already have been exceeded at the point where the lowest concentration was measured. Consequently, the NOEC derived from this approach may be an overestimate. The exact form of the relationship between the response variable and the $\mathrm{NH}_{3}$ concentration may be uncertain, because of the paucity of sampling points. If an inappropriate response function is fitted, or if the data are subject to large measurement uncertainties, then the $95 \%$ confidence intervals will tend to be wide, and the apparent NOEC will again be overestimated. Consequently, the bias in this method is to overestimate the NOEC. Even where a very clear and well-fitted response is observed, the NOEC obtained is specific for the particular site, and includes no 'safety factor' to allow for extrapolation to other sites or conditions, as often used in establishing toxicity thresholds in ecotoxicology.

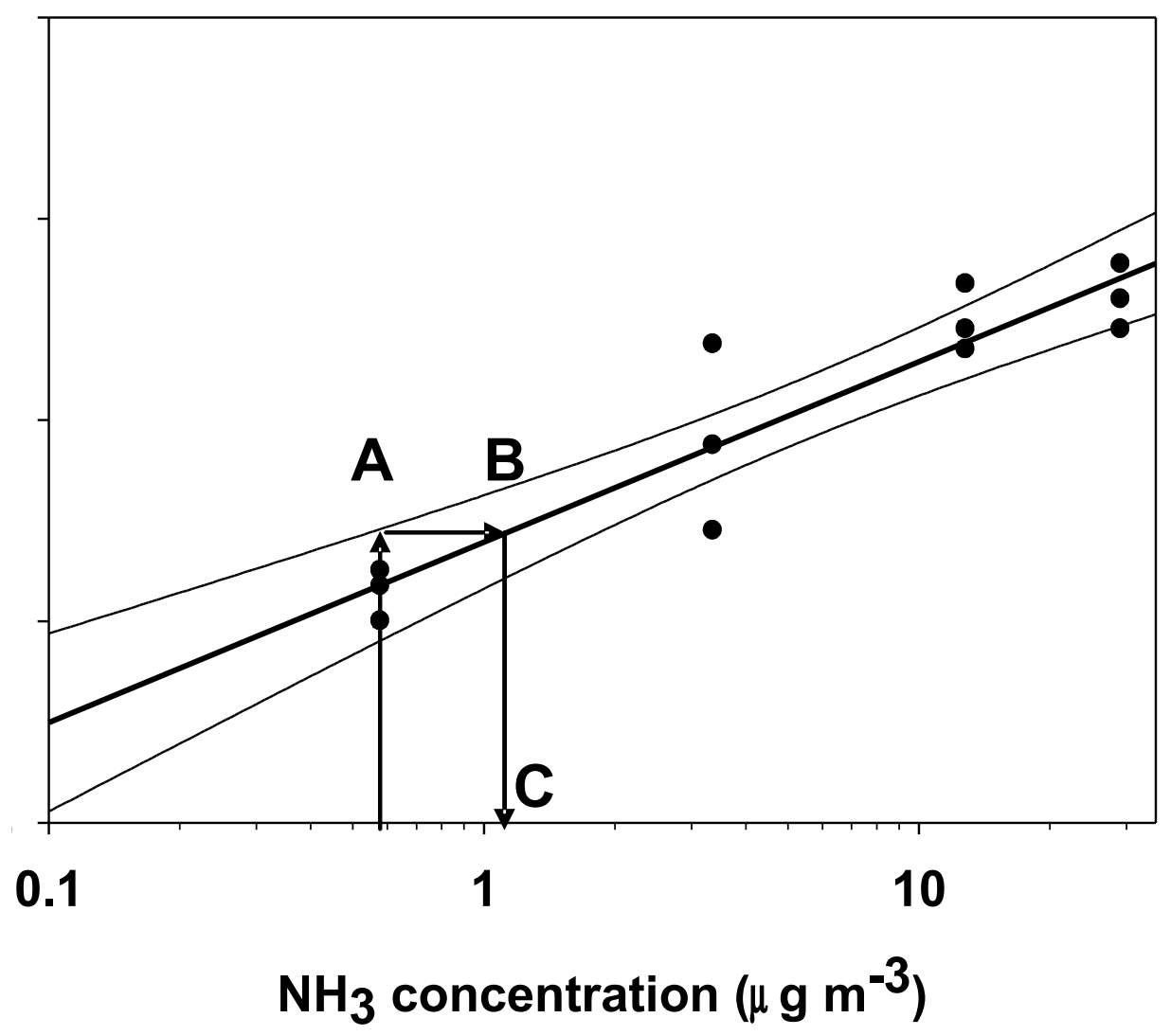

Figure 1. Illustrative example of estimation of the NOEC from measurements at several locations differing in $\mathrm{NH}_{3}$ concentration. The lowest measured concentration (A) is taken as representative of the local 'background' concentration. 


\section{Evidence for adverse effects below the $\mathrm{CLE}_{\mathrm{NH} 3}$ of 1993}

This section reviews recent experimental and observational data that demonstrate measurable changes in vegetation, compared to 'background' conditions, which are directly attributable to (measured) exposure to $\mathrm{NH}_{3}$. Results from measurements on vegetation where the $\mathrm{NH}_{3}$ gas concentration has not been measured are not included (for example, studies where $\mathrm{NH}_{3}$ concentration was only indicated by quoting data relative to distance from a point source), although they may have a bearing on the spatial range over which such effects can be observed.

One of the most comprehensive datasets is from Whim Bog (Sheppard et al., 2008a), reproduced as Figure 2, where the tissue $\% \mathrm{~N}$ of the moss Hypnum jutlandicum (Holmen and Warncke) is plotted in response to long-term average $\mathrm{NH}_{3}$ concentrations after 4.5 years exposure in the field-fumigation experiment at Whim Bog, in south-east Scotland (Leith et al., 2004). In this case, the large number of data points clearly shows the linear response to a logarithmic increase in $\mathrm{NH}_{3}$ concentration, and a calculated $\mathrm{CLE}_{\mathrm{NH} 3}$, as defined above, of $0.8 \mu \mathrm{g} \mathrm{NH}_{3} \mathrm{~m}^{-3}$.

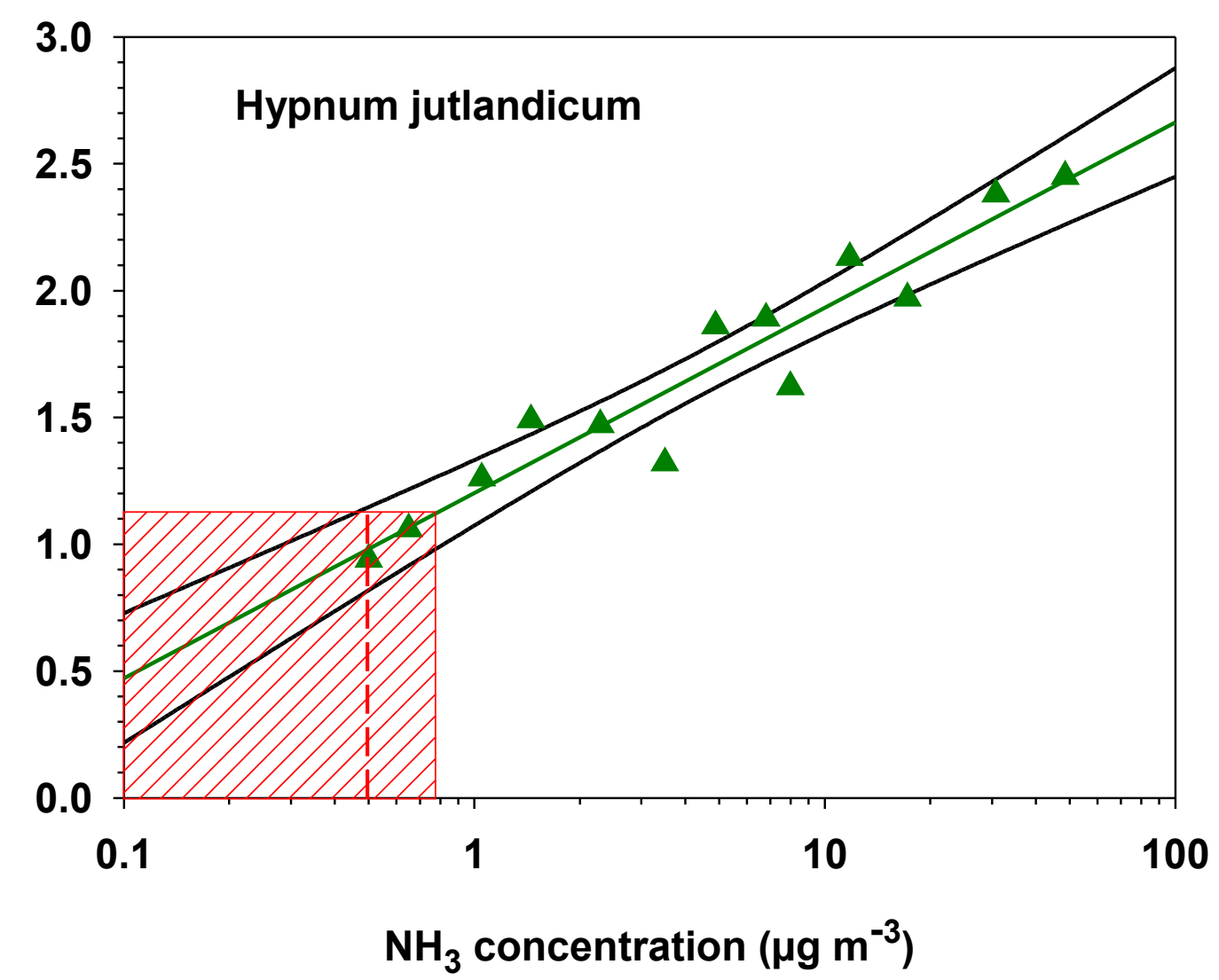

Figure 2. Increase in tissue $\mathrm{N}$ concentration of the moss Hypnum jutlandicum in response to experimental field-fumigation with $\mathrm{NH}_{3}$ after 4.5 years of treatment (data from Sheppard et al., 2008a).

Although this example only shows a measurable response to $\mathrm{NH}_{3}$, which may not be ecologically significant, it illustrates the method using real field data, and shows that plants do respond to $\mathrm{NH}_{3}$ concentrations very much smaller than the current CLE $E_{\mathrm{NH} 3}$. Similar data have been reviewed and summarised elsewhere (Cape et al., 2008), and serve as corroborative evidence for $\mathrm{NH}_{3}$ effects at low concentrations, even though 
the measured response may not (yet) have resulted in changes in species composition or other ecologically relevant outcomes.

The same approach can, however, also be used to examine the effects on community structures of measured gradients in $\mathrm{NH}_{3}$ concentrations downwind of large sources. Several indices of community response have been used: parallel spatial gradients have been shown between $\mathrm{NH}_{3}$ concentrations and Ellenberg $\mathrm{N}$ Index (Leith et al., 2005, Pitcairn et al., 2006). A more sensitive index, derived from the presence/absence of nitrophobe and nitrophile species (Pitcairn et al., 2006, Wolseley et al., 2006), suggested that significant changes in species composition occurred at concentrations between 1 and $3 \mu \mathrm{g} \mathrm{NH}_{3} \mathrm{~m}^{-3}$. More recent data, derived from experiments in the UK, Switzerland, Portugal and Italy, all indicate ecologically significant effects in the range of $0.5-4 \mu \mathrm{g} \mathrm{NH}_{3} \mathrm{~m}^{-3}$ (Frati et al., 2007, Pinho et al., 2008, Rihm et al., 2008, Sutton et al., 2008b). The results of the statistical approach described above to each of these datasets are shown in Table 2. Lichens and bryophytes represent the most sensitive types of vegetation to $\mathrm{NH}_{3}$.

Table 2: Summary of NOECs of the impact of long-term exposure to $\mathrm{NH}_{3}$ on species composition of lichens and bryophytes. NOECs were directly estimated from exposure/response curves or calculated with regression analysis. The data are from recent experimental studies, both field surveys and controlled field experiments on the impact of $\mathrm{NH}_{3}$ on vegetation.

\begin{tabular}{|l|l|l|l|l|}
\hline Location & Vegetation type & $\begin{array}{l}\text { Lowest } \\
\text { measured } \mathbf{~ H}_{3} \\
\text { concentration } \\
\left(\mu \mathbf{g ~ m}^{-3}\right)\end{array}$ & $\begin{array}{l}\text { Estimated } \\
\text { NOEC } \\
\left(\mu \mathbf{g ~ m}^{-3}\right)\end{array}$ & Reference \\
\hline $\begin{array}{l}\text { SE Scotland, } \\
\text { poultry farm }\end{array}$ & Epiphytic lichens & 0.6 & $\begin{array}{l}0.7 \text { (on twigs) } \\
1.8 \text { (on trunks) }\end{array}$ & $\begin{array}{l}\text { (Pitcairn et al., } \\
\text { 2004, Sutton et } \\
\text { al., 2008b) }\end{array}$ \\
\hline $\begin{array}{l}\text { Devon, } \\
\text { SW England }\end{array}$ & $\begin{array}{l}\text { Epiphytic lichens } \\
\text { diversity (twig) }\end{array}$ & 0.8 (modelled) & 1.6 & $\begin{array}{l}\text { (Wolseley et al., } \\
\text { 2006) }\end{array}$ \\
\hline $\begin{array}{l}\text { United Kingdom, } \\
\text { national NH } \\
\text { network }\end{array}$ & Epiphytic lichens & 0.1 & 1.0 & $\begin{array}{l}\text { (Leith et al., 2005, } \\
\text { Sutton et al., } \\
\text { 2008b) }\end{array}$ \\
\hline $\begin{array}{l}\text { Switzerland } \\
\text { SE Scotland, field } \\
\text { NH }{ }_{3} \text { experiment, } \\
\text { Whim bog }\end{array}$ & $\begin{array}{l}\text { Lichens and } \\
\text { bryophytes - } \\
\text { damage and death }\end{array}$ & 0.5 & 2.4 & $\begin{array}{l}\text { (Rihm et al., } \\
\text { 2008) }\end{array}$ \\
\hline Corroborative evidence * & 1.9 (modelled) & $\begin{array}{l}\text { (Sheppard et al., } \\
\text { 2008a) }\end{array}$ \\
\hline SW England & Epiphytic lichens & 1.5 & $<4$ & (Leith et al., 2005) \\
\hline $\begin{array}{l}\text { South Portugal } \\
\text { Epiphytic lichens }\end{array}$ & 0.5 & 2.5 & $\begin{array}{l}\text { (Pinho et al., } \\
\text { 2008) }\end{array}$ \\
\hline Italy, pig farm & Epiphytic lichens & 0.7 & ca. 2 & (Frati et al., 2007) \\
\hline
\end{tabular}

* In these cases $\mathrm{NH}_{3}$ concentration data were available for less than one year, which is why these results are categorised as "corroborative evidence".

\section{Proposal for new CLEs}

The data in Table 2 suggest that the current annual CLE $_{\mathrm{NH} 3}$ does not protect the most sensitive components of ecosystems, namely lichens and bryophytes, and probably also some of the more sensitive higher plant species. The changes in species composition observed for ecosystems that contain lichens and/or bryophytes suggest 
that long-term exposure at concentrations lower than $8 \mu \mathrm{g} \mathrm{NH} \mathrm{N}^{-3}$ would lead to changes in species, and possibly species extinction. In this case, 'long-term' refers to a period of several years, sufficient for such changes to occur. Based on the NOEC data in Table 2, a long-term CLE $\mathrm{NH}_{3}$ for these systems should be set at $1 \mu \mathrm{g} \mathrm{NH}_{3} \mathrm{~m}^{-3}$. For higher plants, there is much less new information, but two studies indicate that the current $\mathrm{CLE}_{\mathrm{NH} 3}$ of $8 \mu \mathrm{g} \mathrm{m}^{-3}$ is too high as a long-term threshold for higher plants in natural vegetation.

(1) Changes in woodland ground flora downwind of an intensive animal unit in SW England suggest a threshold of $4 \mu \mathrm{g} \mathrm{m}^{-3}$ (Leith et al., 2005).

(2) Comparison of the increasing rate of death of Calluna vulgaris at a field fumigation experiment in Scotland (Whim bog) with the death rate of the lichen Cladonia spp. indicates consistently that Calluna death occurs at a concentration 2.2 times that at which Cladonia is killed (Sheppard et al., 2008a); this implies a 'no effect' concentration for Calluna of around $2 \mu \mathrm{g} \mathrm{m}^{-3}$.

On the basis of these results, we propose the long-term $\mathrm{CLE}_{\mathrm{NH} 3}$ for higher plants as 3 $\mu \mathrm{g} \mathrm{NH}_{3} \mathrm{~m}^{-3}$. Although data are sparse, it is likely that the CLE $\mathrm{NH}_{3}$ as defined above would protect bogs, heathland, woodland ground flora and probably also oligotrophic grassland, from $\mathrm{NH}_{3}$-driven shifts in species composition, and the potential for species extinctions.

There is too little experimental information to propose a long-term $\mathrm{CLE}_{\mathrm{NH} 3}$ for all ecosystems or habitats. However, the proposed long-term $\mathrm{CLE}_{\mathrm{NH} 3}$ for higher plants is likely to be no more restrictive than the existing CLO for most habitats, based on estimating the contribution of $3 \mu \mathrm{g} \mathrm{NH} \mathrm{N}_{3}^{-3}$ to dry deposition of $\mathrm{N}$ in most ecosystems. For example, typical values for the UK would be $15-20 \mathrm{~kg} \mathrm{~N} \mathrm{ha}^{-1} \mathrm{y}^{-1}$ for short vegetation, and up to $30 \mathrm{~kg} \mathrm{~N} \mathrm{ha}^{-1} \mathrm{y}^{-1}$ for tall vegetation, in addition to the deposition of other $\mathrm{N}$ species (wet and dry).

\section{Conclusions and recommendations}

The current annual CLE $\mathrm{NH}_{3}$ of $8 \mu \mathrm{g} \mathrm{NH}_{3} \mathrm{~m}^{-3}$ is of little practical use because it was not defined in terms of sensitive ecosystems, and because it is not as precautionary as empirical Nitrogen Critical Loads for most of the semi-natural habitat types of Europe. Clear evidence has emerged, especially from field studies in the UK, but also from several other European countries, of effects of $\mathrm{NH}_{3}$ on vegetation at concentrations well below the current annual $\mathrm{CLE}_{\mathrm{NH} 3}$. Based on that evidence, a longterm $\mathrm{CLE}_{\mathrm{NH} 3}$ of $1 \mu \mathrm{g} \mathrm{NH} \mathrm{m}^{-3}$ can be assumed to be protective for biodiversity of most sensitive ecosystems. A long-term $\mathrm{CLE}_{\mathrm{NH} 3}$ of $3 \mu \mathrm{g} \mathrm{NH}_{3} \mathrm{~m}^{-3}$ is probably protective for biodiversity of systems if bryophytes and lichens are not included.

Despite the progress made in recent years, several uncertainties still remain. Additional work is required to allow inter-conversion of CLEs and CLOs. In particular, uncertainty exists as to the appropriate deposition velocities linking CLEs and CLOs for climatic zones outside the western maritime conditions of western Europe, especially for colder and drier climates. As with the CLO, it is expected that interactions with other plant stresses will modify the CLE, although there are few data on the quantitative interaction with high and low temperatures or drought stress. There are some indications, for example, that cold and drought stress make Calluna more sensitive to $\mathrm{NH}_{3}$ (Sheppard et al., 2008b). The presence of other pollutants may also affect the response of vegetation to $\mathrm{NH}_{3}$, particularly at low concentrations of $\mathrm{NH}_{3}$. There are major gaps in our knowledge of the deposition behaviour and compensation 
points of $\mathrm{NH}_{3}$, and the relative importance of the different $\mathrm{N}$ compounds that contribute to CLOs.

We recommend:

that the 'long-term' annual average Critical Level (CLE $\left.\mathrm{NH}_{\mathrm{N} 3}\right)$ for lichens, bryophytes, and for ecosystems in which they are important, be set at $1 \mu \mathrm{g} \mathrm{NH}_{3} \mathrm{~m}^{-3}$;

that the 'long-term' annual average Critical Level $\left(\mathrm{CLE}_{\mathrm{NH} 3}\right)$ for higher vegetation be set at $3 \mu \mathrm{g} \mathrm{NH}_{3} \mathrm{~m}^{-3}$, recognizing that this figure is more uncertain, and that it should be expressed as a range of $2-4 \mu \mathrm{g} \mathrm{NH} \mathrm{m}^{-3}$

In defining the $\mathrm{CLE}_{\mathrm{NH} 3}$ in terms of air concentrations, it is assumed that appropriate methods are available to measure $\mathrm{NH}_{3}$. For long-term averages, passive diffusion samplers provide adequate precision and accuracy (Leith et al., 2004, Sutton et al., 2001, Tang et al., 2001), but care must be taken with their deployment in the field. The CLE $\mathrm{NH}_{3}$ defined above are based on $\mathrm{NH}_{3}$ concentrations measured at a height of 1-2 $\mathrm{m}$ above the vegetation surface. Where the surface is an important sink for $\mathrm{NH}_{3}$ there will be marked vertical concentration gradients (Cape et al., 2008), so that the measurement height in relation to the $\mathrm{CLE}_{\mathrm{NH} 3}$ becomes important, and should also be standardized, for example at $1.5 \mathrm{~m}$ above the surface of short vegetation.

The proposed $\mathrm{CLE}_{\mathrm{NH} 3}$ are based on empirical evidence for responses of the sensitive species within a community. Directly applicable quantitative information on causal relations and on inter-species variation in sensitivity is still scarce. Deriving methods for linking physiological and biochemical measurements on plants to observed shifts in species composition would greatly assist in detailed analysis of existing information. Ecosystem models that simulate $\mathrm{N}$ cycles and biomass production could be useful, but are still in a preliminary state of development for the purpose of assessing CLE $\mathrm{NH}_{\mathrm{NH}}$.

\section{References}

Ashmore, M.R., Wilson, R.B. (Eds.), 1994. Critical Levels of Air Pollutants for Europe. Department of the Environment, London, 209 pp.

Cape, J.N., Sheppard, L.J., Binnie, J., Arkle, P., Woods, C., 1995. Throughfall deposition of ammonium and sulphate during ammonia fumigation of a Scots pine forest. Water Air and Soil Pollution 85 (4), 2247-2252.

Cape, J.N., van der Eerden, L.J., Sheppard, L.J., Leith, I.D., Sutton, M.A., 2008. Reassessment of Critical Levels for ammonia. In: Sutton, M.A., Baker, S., Reis, S. (Eds.), Atmospheric Ammonia: Detecting emission changes and environmental impacts. Springer, in press.

Fangmeier, A., Hadwiger-Fangmeier, A., van der Eerden, L., Jäger, H.J., 1994. Effects of Atmospheric Ammonia on Vegetation - A Review. Environmental Pollution 86 (1), 43-82.

Frati, L., Santoni, S., Nicolardi, V., Gaggi, C., Brunialti, G., Guttova, A., Gaudino, S., Pati, A., Pirintsos, S.A., Loppi, S., 2007. Lichen biomonitoring of ammonia emission and nitrogen deposition around a pig stockfarm. Environmental Pollution 146 (2), 311-316.

Krupa, S.V., 2003. Effects of atmospheric ammonia $\left(\mathrm{NH}_{3}\right)$ on terrestrial vegetation: a review. Environmental Pollution 124 (2), 179-221.

Leith, I.D., Sheppard, L.J., Fowler, D., Cape, J.N., Jones, M., Crossley, A., Hargreaves, K.J., Tang, Y.S., Theobald, M., Sutton, M.A., 2004. Quantifying 
dry $\mathrm{NH}_{3}$ deposition to an ombrotrophic bog from an automated $\mathrm{NH}_{3}$ field release system. Water, Air, \& Soil Pollution: Focus 4 (6), 207-218.

Leith, I.D., van Dijk, N., Pitcairn, C.E.R., Wolseley, P.A., Whitfield, C.P., Sutton, M.A., 2005. Biomonitoring methods for assessing the impacts of nitrogen pollution: refinement and testing. ISSN 0963 8901, JNCC, Peterborough.

Perez-Soba, M., van der Eerden, L.J.M., Stulen, I., Kuiper, P.J.C., 1994. Gaseous Ammonia Counteracts the Response of Scots Pine Needles to Elevated Atmospheric Carbon-Dioxide. New Phytologist 128 (2), 307-313.

Pinho, P., Branquinho, C., Cruz, C., Tang, S.Y., Dias, T., Rosa, A.P., Máguas, C., Louçãoa, M.A.M., Sutton, M.A., 2008. Assessment of critical levels of atmospherically ammonia for lichen diversity in cork-oak woodland, Portugal. In: Reis, S., Sutton, M.A. (Eds.), Atmospheric Ammonia - Detecting emission changes and environmental impacts Springer, Berlin, in press.

Pitcairn, C.E.R., Leith, I.D., Sheppard, L.J., Sutton, M.A., 2006. Development of a nitrophobe/nitrophile classification for woodlands, grasslands and upland vegetation in Scotland. AS06/03 for SEPA, Centre for Ecology \& Hydrology, Penicuik.

Pitcairn, C.E.R., Leith, I.D., Sheppard, L.J., van Dijk, N., Tang, Y.S., Wolseley, P.A., James, P., Sutton, M.A., 2004. Feild intercomparison of different bio-indicator methods to assess the effects of atmospheric nitrogen deposition. In: Sutton, M.A., Pitcairn, C.E.R., Whitfield, C.P. (Eds.), Bioindicator and biomonitoring methods for assessing the effects of atmospheric nitorgen on statutory nature conservation sites. JNCC Report 356, pp. 168-177.

Pitcairn, C.E.R., Skiba, U.M., Sutton, M.A., Fowler, D., Munro, R., Kennedy, V., 2002. Defining the spatial impacts of poultry farm ammonia emissions on species composition of adjacent woodland ground flora using Ellenberg Nitrogen Index, nitrous oxide and nitric oxide emissions and foliar nitrogen as marker variables. Environmental Pollution 119 (1), 9-21.

Posthumus, A.C., 1988. Critical levels for effects of ammonia and ammonium., Proceedings of the Bad Harzburg Workshop. UBA, Berlin, pp. 117-127.

Pryor, S.C., Gallagher, M., Sievering, H., Larsen, S.E., Barthelmie, R.J., Birsan, F., Nemitz, E., Rinne, J., Kulmala, M., Groenholm, T., Taipale, R., Vesala, T., 2008. A review of measurement and modelling results of particle atmospheresurface exchange. Tellus Series B-Chemical and Physical Meteorology 60, $42-75$.

Rihm, B., Urech, M., Peter, K., 2008. Mapping Ammonia Emissions and Concentrations for Switzerland - Effects on Lichen Vegetation. In: Sutton, M.A., Baker, S., Reis, S. (Eds.), Atmospheric Ammonia - Detecting emission changes and environmental impacts Springer, Berlin, in press.

Shaw, P.J.A., McLeod, A.R., 1995. The effects of $\mathrm{SO}_{2}$ and $\mathrm{O}_{3}$ on the foliar nutrition of Scots pine, Norway spruce and Sitka spruce in the Liphook open-air fumigation experiment. Plant Cell and Environment 18 (3), 237-245.

Sheppard, L.J., Leith, I.D., Crossley, A., van Dijk, N., Fowler, D., Sutton, M.A., 2008a. Long-term cumulative exposure exacerbates the effects of atmospheric ammonia on an ombrotrophic bog: Implications for Critical Levels. In: Sutton, M.A., Baker, S., Reis, S. (Eds.), Atmospheric Ammonia - Detecting emission changes and environmental impacts Springer, Berlin, in press.

Sheppard, L.J., Leith, I.D., Crossley, A., van Dijk, N., Fowler, D., Sutton, M.A., Woods, C., 2008b. Stress responses of Calluna vulgaris to reduced and 
oxidised $\mathrm{N}$ applied under 'real world conditions' Environmental Pollution in press.

Sutton, M.A., Baker, S., Reis, S. (Eds.), 2008a. Atmospheric Ammonia - Detecting emission changes and environmental impacts Springer, Berlin, in press

Sutton, M.A., Miners, B., Tang, Y.S., Milford, C., Wyers, G.P., Duyzer, J.H., Fowler, D., 2001. Comparison of low cost measurement techniques for long-term monitoring of atmospheric ammonia. Journal of Environmental Monitoring 3 (5), 446-453.

Sutton, M.A., Wolseley, P.A., Leith, I.D., van Dijk, N., Tang, Y.S., James, P.W., Theobald, M.R., Whitfield, C.P., 2008b. Estimation of the ammonia critical level for epiphytic lichens based on observations at farm, landscape and national scales. In: Sutton, M.A., baker, S., Reis, S. (Eds.), Atmospheric Ammonia - Detecting emission changes and environmental impacts Springer, Berlin, pp. in press.

Tang, Y.S., Cape, J.N., Sutton, M.A., 2001. Development and types of passive samplers for monitoring atmospheric $\mathrm{NO}_{2}$ and $\mathrm{NH}_{3}$ concentrations. The Scientific World 1, 513-529.

van der Eerden, L.J., Dueck, T.A., Berdowski, J.J.M., Greven, H., van Dobben, H.F., 1991. Influence of $\mathrm{NH}_{3}$ and $\left(\mathrm{NH}_{4}\right)_{2} \mathrm{SO}_{4}$ on heathland vegetation. Acta Botanica Neerlandica 40 (4), 281-296.

van der Eerden, L.J., Dueck, T.A., Posthumus, A.C., Tonneijck, A.E.G., 1994. In: Ashmore, M.R., Wilson, R.B. (Eds.), Critical Levels of Air Pollutants for Europe. Department of the Environment, Air Quality Division, London, pp. 55-63.

van der Eerden, L.J., Sheppard, L.J., Sutton, M.A., 2008. Considerations at defining Critical Levels for $\mathrm{NH}_{3}$. In: Sutton, M.A., Baker, S., Reis, S. (Eds.), Atmospheric Ammonia - Detecting emission changes and environmental impacts Springer, Berlin, pp. in press.

WHO, 1997. Effects of atmospheric nitrogen compounds (particularly nitrogen oxides) on plants, Nitrogen Oxides (Second Edition), Environmental Health Criteria 188. World Health Organisation, Geneva, pp. 115-192.

Wolseley, P.A., James, P.W., Theobald, M.R., Sutton, M.A., 2006. Detecting changes in epiphytic lichen communities at sites affected by atmospheric ammonia from agricultural sources. Lichenologist 38, 161-176. 